\title{
EREDIENS EN KOLLEKTE
}

Die Heidelbergse Kategismus verklaar in Sondag 38: ,... en dat ek, veral op die sabbat, dit is op die rusdag, met die gemeente van God ywerig moet opkom om die Woord van God te hoor, ... en aan die armes Christelike liefdegawes te bring; ..." Die bewysplek uit die Skrif vir hierdie laaste stelling, is I Kor. $16: 2$ wat lui: ,Op elke eerste dag van die week moet elkeen van julle opsy sit en opspaar namate sy voorspoed is, sodat die insameling nie eers plaasvind as ek kom nie". Hier is wel sprake van die kollekte miar sonder direkte verband met die erediens. Dit kan die Kategismus egter nie ten kwade gedui word nie, omdat dit geen dogmatiese handboek is nie en die bedoeling dus ook nie is om uitputtend te wees met betrekking tot Skrifuitsprake wat die saak stel nie. Die gebruik in die kerk om met die erediens te kollekteer rus in elk geval op die Belydenis. Daarom sal dit goed wees om die gegewens wat die Skrif hieroor bied, te probeer naspeur.
1. Waarom word gekollekteer?

Die apostel Paulus handel op verskillende plekke oor 'n kollekte - in Handel. 11 : 27; 24 : 17; Rom. 15 : 25 vv.; I Kor. 16 : 1vv.; 2 Kor. 8 en 9 ; Gal. $2: 10$. Om te verstaan waaroor dit handel moet ons die agtergrond van die saak ken, naamlik dat onder die Christene in Jerusalem armoede gekom het -.stellig as gevolg van die vervolgings on waarskynlik ook omdat die eerste liefde (vgl. Hand. 2 : 44vv.) verflou het. Om hierdie toestand te verhelp, het die Christene van elders geld bymekaar gemaak vir die heiliges in Jerusalem. Vir hierdie lofwaardige saak het Paulus hom baie beywer, en daarom skryf hy ook telkens daaroor.

Om die gedagtegang van Paulus te begryp, moet ons begin deur te let op wat hy oor Christus self gesê het. Ons lees in 2 Kor. $8: 9$ dit: "Want julle ken die genade van onse Here Jesus Christus, dat $\mathrm{Hy}$, alhoewel $\mathrm{Hy}$ ryk was, ter wille van julle arm geword het, sodat 
julle deur sy armoede ryk kan word". Die aandag word gevestig op die onskatbare betekenis van Christus se koms en werk. Sy rykdom verwys natuurlik na Sy heerlike goddelikheid (vgl. Filipp. $2: 6$ ), en die arm word dui op Sy vernedering. $\mathrm{Hy}$, die Seun van God, het die menslike natuur aangeneem - daardie natuur wat gebuk gaan onder die gevolge van die sonde - en in dié natuur het Hy ook gely en gesterwe (vgl. Filipp. 2 : $7 \mathrm{v}$.). Dink verder aan Sy armoede: dat $\mathrm{Hy}$ in die krip neergelê is, en geen plek gehad het om Sy hoof neer te lê nie. In Sy vernedering het $\mathrm{Hy}$ versoening bewerk, waardeur die sondaar weer aangeneem word tot kind van God en ook met wonder-ryke gawes van God begenadig word. Omdat die Saligmaker arm geword het, kan Hy arme sondaars dus ryk maak - die "ter wille van julle" ontvang in die grondtaal besondere nadruk. Ons is as mense dus arm in onsself, maar ons beklaenswaardige toestand word deur die genade in Christus Jesus, as gawe van God, opgehef. Alleen deur Christus, en mits ons aan Hom verbonde is, ontvang ons hierdie voorreg en voordeel.

Insiggewend is verder wat Rom. $15: 26 \mathrm{v}$. bied. Ons lees daar dat sekere gemeentes ,dit goedgevind het om iets by te dra vir die armes onder die heiliges in Jerusalem". 'n Direkte vertaling van die grondteks sou ongeveer so lees: "... goedgevind om 'n (bewys van) gemeenskap te gee aan die armes..." Die woord gemeenskap is baie belangrik hier. Dit kom ook voor in 1 Kor. 1 : 9 gemeenskap met sy Seun Jesus Christus, onse Here); 1 Kor. 10 : 16 (gemeen- skap met die bloed en liggaam van Christus); 2 Kor. 6 : 14 (watter gemeenskap het die lig met die duisternis); Filipp. 1 : 5 (oor julle gemeenskap aan die evangelie). Hierdie woord (koinonia) is in die N.T. volgelaai met betekenis. Dit wys eerstens op die gemeenskap met en verbondenheid aan Christus, soos bv. by die Nagmaal blyk. Maar verder is dit so dat die Christus-gemeenskap voer tot die Christen-gemeenskap — deur die band aan Christus is die gelowiges ook aan mekaar verbonde. Juis dit is die rede waarom die ander kerke aan die gelowiges in Jerusalem hulp bied.

Dieselfde Skrifgedeelte bied egter nog meer stof. Paulus sê ook: "want as die heidene deel gekry het aan hulle geestelike voorregte, is hulle ook verskuldig om hulle met stoflike goedere te dien". Hier word nou van 'n sedelike verpligting gespreek. Die ,geestelike voorregte" dui eerstens op die Evangelie wat vanuit Jerusalem uitgedra is (vgl. Luk. $24: 47$; Joh. 4 : 22; Hand. $1: 8$ ), en verder word deur die Evangelie die heilsgoedere, die werklike verlossing deur Christus, gebring (vgl. Luk. 4 : 17 vv.). Die heidene was eers ver van God en die bevryding in Christus, maar die predikers het uitgegaan en só het hulle die lig van die Evangelie ontvang, en is hulle gered. Skuldenaars, sê Paulus, en gebruik dan dieselfde woord as in Rom. $13: 8-$,Wees aan niemand iets skuldig nie, behalwe om mekaar lief te hê". Die gesindheid van liefde moet dus onder die Christene heers, juis omdat Christus hulle eerste liefgehad het en dit ten spyte van die feit dat hulle sondaars (of armes) is. Hierdie liefdesplig 
is só hoog en wyd en diep dat dit nooit sy einde vind nie. Uit erkentlikheid dat hulle (die heidene), deur bemiddeling in Christus - en omdat hulle geestelike armoede so opgehef is - bied hulle stoflike hulp aan die materieel-minder-gegoedes van Jerusalem.

In hierdie verse van Romeine praat Paulus van dien en dan gebruik hy 'n woord wat aandui priesterlike diens aan God (vgl. Luk. 1 : 23; Hand. 13 : 2; Filipp. 2 : 17, 30 ; Hebr. $8: 6 ; 9: 21$; $10: 11)$. Sommige verklaarders meen dat in Rom. 15 : 27 nie van heilige diens sprake is nie, maar dat dit bloot net diensbetoon in 'n alledaagse toonaard aandui. Maar Jakobus 1 : 27 stel tog duidelik dat hulp aan weduwees en wese reine en onbesmette godsdiens is voor God. Daarom sê Greydanus oor hierdie diens (leitourgia - liturgiese diens) in Rom. 15: „Met hierdie woord word ook die bied van stoflike hulp aan die behoeftige gelowiges as 'n heilige diens voorgestel, as 'n priesterlike diens aan God - dit is diens aan God in 'n baie besondere $\sin .$. Tydens die behandeling het die punt onder bespreking 'n breër aspek verkry ... en die apostel toon aan dat die gelowiges uit die heidene uit dankbaarheid en as ter weervergelding nou ook die stoflike node van die Jode moet vervul, in hierdie geval van die arm gelowiges in Jerusalem". (Bottenburg, p. 649). Die Verklarende aantekenings by die Afrikaanse Bybel stel ook: "Stoflike hulp aan behoeftiges word gesien as priesterlike werk."

Ons vind dieselfde woord ook in 2 Kor. 9 : 12 (Want die bediening van hierdie hulpbetoning ...) waar ook uit- druklik van danksegginge aan God gespreek word. Maar hier verskyn verder nog ' $n$ ander betekenisvolle woord wat met bediening vertaal word. In die grondtaal is dit diakoneo (dink aan diaken). Die woord dui aan 'n heeltemal persoonlike diensbewys wat aan 'n ander betoon word, waarby die gedagte aan liefdesdiens baie sterk is. Naasteliefde was in die O.T. al bekend en voorgeskryf, maar dit ontvang besondere beklemtoning en herwaardering deur Jesus, veral in verbinding met die liefde tot God. By Jesus self bly dit nie net by woorde nie, maar is dit vervulde werklikheid in die diens van die hoog. ste liefdesdaad deurdat Hy Homself prysgegee het vir die wêreld. Daarom kon $\mathrm{Hy}$ sê: „Ek is onder julle soos een wat dien" (Luk. 22 : 27). Wat Christus gedoen het, moet deur elkeen van $\mathrm{Sy}$ volgelinge ook gedoen word, want in diens sien Jesus dié houding van die dissipel (vgl. Joh. 12 : 26; Matth. 25 : 40 - „Voorwaar Ek sê vir julle vir sover julle dit gedoen het aan een van die geringstes van hierdie broeders van $\mathrm{My}$, het julle dit aan My gedoen"). Dit vorm alles die agtergrond van wat Paulus hier sê, en só noem hy hierdie kollekte 'n „diakonale diens". Duidelik spreek dit uit 2 Kor. 8 en 9 ( $8: 4,19,20 ; 9: 1$, $12,13)$, waarby Paulus stel dat dit nie net 'n uitwendige aangeleentheid is as hulle hulp bied nie, maar as 'n werklike liefdesdaad verstaan moet word. Ridderbos sê dat hierdie woord (diakonia) gebruik word van onderlinge diensbetoon in die gemeente, spesiaal ook in materiële verband (Romeine, Kok, p. 336).

'n Treffende verbinding van begrip- 
pe vind ons in 2 Kor. $8: 4$ waar sprake is van ,...hulle deel aan die diensbetoning aan die heiliges..." In hierdie uitspraak is verbind die woord gemeenskap (koinonia) en diens (diakonia). Uit die band met Christus en aan mekaar vloei dus hierdie liefdesdiens voort. Daarom wek dit geen verbasing nie om te hoor dat Paulus hier kan praat van die genade van God wat geskenk is, en wat juis daarin bestaan dat die gelowiges iets aan ander gegee het. Gewoonlik verstaan ons genade so dat die mens iets ontvang (bv. verlossing uit sonde wat deur God aan hom gegee word). Hier egter bestaan die genade juis daarin dat hulle milddadigheid beoefen het - dus aan ander geskenk het - terwyl hulle dit self nie volop gehad het nie. Soos wat, en omdat Gods genade in Christus geskenk het, dra hulle dit verder uit. Daarom kan dit beslis as liefdesdaad of liefdework bestempel word. Elders in die Skrif word hierdie waarheid pragtig weergegee: „Namate elkeen 'n genadegawe ontvang het, moet julle mekaar daarmee dien soos goeie bedienaars van die veelvuldige genade van God" (1 Petrus $4: 10$ ). Dit is dus genade as jy ook kan uitdeel! Diegenc wat gehelp word, en hulle wat help, werk tot verheerliking van God.

Oor die praktiese sy van die kollekte bied die Skrif ons ook lig. Die belangrikste gedeelte hieroor is 1 Kor. $16: 1-4$, waar die insameling ter sprake kom. Twee sake tref hierby die aandag, naamlik dat daar elke eerste dag van die week opsy gesit moet word en dit moet gebeur namate elkeen se voorspoed is. Eers wil ons die aandag by die eerste van hierdie opdragte bepaal.

Die Joodse Sabbat is natuurlik op die laaste dag van die week gevier. Met die koms en as gevolg van die werk van Christus het hierin verandering gekom, deurdat die rusdag na die eerste dag van die week verplaas is. Hierdie dag was immers die dag van die opstanding van die Here. Meer as egter net hierdie historiese gegewenheid het veroorsaak dat die eerste dag van die week nou as Rusdag in ere gehou word. Dit hang naamlik saam met die hele karakter van die genadeverbond. Nie meer hoef die mens eers te werk om die rus te verdien nie, maar ons lewe begin deur te rus in die volbragte werk van Christus, en daarna arbei ons met dankbaarheid. Ons lees van die dissipels wat op die eerste dag van die week vergader het (Joh. $20: 19$ ) en Handel. $20: 7$ vertel ook van 'n samekoms van die gemeente op dié dag. Om baie besondere en gegronde redes is die eerste dag van die week dus as ' $n$ besondere dag gevier, en juis op daardie dag was ook besondere samekomste van die gemeente. Die direkte betrekking van hierdie dag op Christus en die verlossing wat $\mathrm{Hy}$ bewerk het, is duidelik en die gemeentesamekomste op dié dag ook beslis sinvol.

Paulus stel geen direkte verband tussen die samekomste en die kollekte nie. In die Skrif vind ons ook geen direkte uitspraak daaroor nie. Deurdat die Christelike Kerk toe nog in sy beginstadium was, vind ons weinig direkte uitsprake oor die erediens en sy orde. sodat ons uit die beginsels gevolgtrekkings moet maak vir hierdie sake. Paulus spreek nou van opsy-sit op die 
eerste dag. Nou kan ons die afleiding maak dat dit volkome in ooreenstemming met die gegewens van die Skrif is om die afdra van die kollekte en die erediens bymekaar te voeg. $D$ is 'n samekoms van die gemeente van Christus waar hulle opnuut weer die rykdom van die Woord ontvang en daarmee die genade van God. Christus se werk en offer word weer eens duidelik na vore gebring. Daar is gemeenskap met Hom, en daardeur opnuut met mekaar. In die lig van al hierdie faktore word hierdie onderlinge gemeenskap duidelik en prakties tot uiting gebring deurdat die meerbevoorregtes só gee dat in die behoeftes van hul armer geloofsgenote voorsien kan word. Op dié wyse tree ook in werking die weervergelding vir die rykdom van die Evangelie wat in die bediening van die Woord tot die gemeente gekom het (die skuldig van Rom. 15). Die betekenis van die Rusdag word sinvol uitgedruk en verder verdiep deur die samekoms van die gemeente in die erediens, en aan die ander kant kan die erediens as die konsentrasiepunt of uitkristallisering van die Rusdag beskou word. Daarom kan die opsy-sit van 'n gawe vir die heiliges nêrens mooier en doeltreffender as in die erediens werklikheid word nie. Die direkte betrekking van hierdie dag met Christus en Sy verlossingswerk is voor die hand liggend, en die samekomste van die gemeente op dié dag uiters sinvol. Liefde en genade word ontvang, en betoon, deur die Christene!

Hierby moet nog iets gevoeg word. Ons lees in die Skrif van liefdesmaaltye (1 Kor. 11 : 17vv.). Wat daar gebeur het, was dat die gemeente saamgekom het vir 'n gemeenskaplike maaltyd, waarby die rykes baie lewensmiddele saamgebring het en die armes weinig of niks, maar deurdat almal saam geëet het, het die armes genoeg voedsel gekry om te eet en is in hulle behoeftes voorsien. Dit is dan 'n liefdesmaaltyd, 'n soort van diakonale hulpbetoon (Grosheide). Hoewel dit heelwaarskynlik daagliks of gereeld plaasgevind het, is vir ons onderwerp van belang dié feit dat voorsiening in die behoeftes van die armer geloofsgenote deel gevorm het van die samekomste van die gemeente. Dieselfde gebruik en waarheid vind ons ook in Handel. 6 : 1vv., waar sprake is van die daaglikse versorging van die weduwees en van die bediening van die tafels, wat kan heenwys na liefdesmaaltye of kan beteken die verdeling onder die armes van die opbrengs van die verkoopte goedere (Grosheide). Ons moet daarop let dat die versorging van die armes baie beslis aandag geniet het by die samekoms van die gemeente. Dit blyk ook daaruit dat die apostels hierdie noodsaaklike diens nie wou laat skade ly nie, maar ontheffing van hierdie verpligting gesoek het. So kon hulle hul toewy aan die bediening van die Woord, en die armes is na behore versorg.

Uit 1 Kor. 16 moet ons terugkom op die reeds genoemde tweede saak, waar sprake is van die opsy-sit namate elkeen se voorspoed is. Dus nie die minste moet gegee word of enige willekeurige bedrag nie, dog volgens wat elkeen van die Here ontvang het. Dieselfde waarheid lees ons waar elders geskrywe staan: „Want as die bereidwilligheid 
daar is, is dit welgevallig volgens wat iemand besit, nie volgens wat hy nie besit nie" ( 2 Kor. 8 : 12). Ook dít nog: „Laat elkeen gee soos hy hom in sy hart voorneem, nie met droefheid of uit dwang nie, want God het 'n blymoedige gewer lief" (2 Kor. $9: 7$ ). Die woorde van die Skrif is so duidelik dat verder verklaring oorbodig is. Ons moet wel aandag gee aan die vrywilligheia waarmee die gelowige gee (omdat en soos hy deur God daartoe beweeg word) en dat sy gawe in die regte verhouding tot sy inkomste moet wees. Verder dink ons weer daaraan dat God juis gee sodat aan ander met vreugde meegedeel kan word.

Die gegewens wat die Skrif bied, kan soos volg opgesom word:

a. Dit is noodsaaklik om op Christus te let om die kollekte reg te verstaan Hy wat ryk was, het arm geword sodat die arme sondaar deur Hom ryk gemaak $k: \mathrm{n}$ word.

b. Alleen hy wat in gemeenskap met Christus staan, word hierdie rykdom deelagtig. Deel van sy rykdom bestaan egter ook daarin dat hy wat eers geïsoleer en op homself aangewys was, in gemeenskap met ander gelowiges, as lede van die liggaam van Christus, gebring word en dat hulle almal 'n band met mekaar het en na mekaar moet omsien.

c. Geestelike seëninge wat langs dié weg verkry word, verplig tot die verlening van materiële hulp. Dit geskied uit dankbare erkentlikheid vir die groot gawe van die Evangelie en die genade in Christus. Om te gee is ook genade.

d. Liefdesdiens aan mekaar moet die grondreël wees in die gemeenskap van die Christelike Kerk, en hierdie liefde moet in konkrete dade tot uitdrukking kom, soos o.a. in 'n gawe vir die kollekte vir die stoflik minder-bevoorregtes.

e. Hierdie liefdewerk self is aangenaam voor God, maar ook die dankkaarheid by diegene wat hulp ontvang, strek tot verheerliking van God. So begin, en eindig, hierdie Christelike aktiwiteit by God.

f. Die gawe vir die versorging van die armes moet op die Rusdag gebring word. Dit gebeur die beste en sinvolste by die erediens, waar God se volk op die dag vergader.

g. Elkeen moet gee volgens wat hy voorspoed van God ontvang het.

God vra van ons totale oorgawe en volle diens. Ook my gawe in die kollekte vir die behoeftes van die heiliges vorm 'n wesenlike deel van my godsdiens dis priesterlike diens aan God. Ja, juis die afdra van stoflike middele of geld is 'n wesenlike bestanddeel van my diens en toewyding aan die Here. Uit dankbaarheid vir die rykdom van die Woord en die geweldige rykheid van die genade wat deur die Woord tot my kom en wat in Christus verniet aan my geskenk word, en omdat ek dit verskuldig is, gee ek sodat ook deur my offergawe vandag nog voorsiening gemaak kan word in die behoeftes van die armer geloofsgenote.

Uit Hom, deur Hom, en tot Hom is alle dinge!

2. Waarvoor moet gekollekteer word?

Die Skrif beveel ons dus om die kollekte vir die behoeftes van die armes te hou. Uit die Skrif blyk verder dat die 
paslikste geleentheid daarvoor by die erediens is. Dit is egter nodig om presies te bepaal waarvoor hierdie kollekte bestem moet wees, d.i. mag dit alleen vir die armes (as persone) wees of kan dit ook vir ander doeleindes afgesonder word? Ook hieroor moet ons die lig van die Skrif soek.

Twee soorte van versorging word in die Bybel genoem, naamlik van armes en van bedienaars van die Woord. Oor hierdie laaste sê Paulus in 1 Kor. 9 dit: .,As ons vir julle die geestelike gesaai het, is dit 'n groot saak as ons julle stoflike goedere maai?" Slaan ook Gal. 6 : 6 na. Hoewel hierdie versorging buite die bestek van ons onderwerp val, moet ons tog iets in verband daarmee bepaal om die hele saak duidelik te kan sien. Ons lees naamlik dit: ,So het die Here ook vir die wat die evangelie verkondig, bepaal dat hulle van die evangelie moet lewe" (1 Kor. 9 : 14). Hier lees ons van ' $n$ bevel van die Here, wat 'n verband lê tussen die verkondiging van die Evangelie en die versorging van hulle wat dit doen. Ons herinner daaraan dat in Rom. 15 ook gepraat is van skuldige plig van die heidene teenoor diegene wat die Evangelie aan hulle gebring het; stoflike hulp moet gebied word uit dankbaarheid vir die geestelike rykdom wat ontvang is. Die bring van die Woord skep dus in albei gevalle verpligtings. En tog is daar onderskeid by die ontvangers, wat veral daarin uitkom dat die versorging van hulle wat die diens van die Woord behartig, 'n reg is. Die bedienaars moet hulle hele lewe wy aan hul ampspligte en kan dus nie elders 'n inkomste soek nie, sodat hulle aanspraak kan maak op versorging deur die kerk. Van die kant van die gemeente bestaan dus 'n plig om te sorg vir die diens van die Woord, o.a. deur versorging van die bedienaars van die Woord. Die armes daarenteen het geen reg waarop hulle aanspraak kan maak om versorg te word nie - dit is 'n genade-voorreg wat geskenk word.

Kruijf (Liturgiek) sê derhalwe tereg dat wat jy vir die kerk gee, is geen liefdegawe nie maar skuld wat $j y$ as lid van die gemeente moet nakom. Daar bestaan dus verskil tussen kerklike bydrae (vir die onderhoud van die kerk, waaronder die diens van die Woord) en 'n liefdegawe vir die armes. Biesterveld (Het Diaconaat) sê hieroor dat daar vir die traktement en rekenings hoofdelike omslag op die lede van die gemeente moet wees, omdat dit 'n kontrak met vasgestelde verpligtings geld. Die saak is derhalwe so dat ek nie maar vir die kerk kan gee of nie gee nie, asof dit van my oordeel afhang - nee, ek moet gee volgens die welvaart wat God nan my geskenk het. Hierdie verpligting moet nagekom word deurdat die mens eers 'n bepaalde persentasie van sy inkomste afgee en daarná kom sy eie verpligtings a:an die beurt. Deel van hierdie laaste verpligtings is die gawe wat vir die behoeftige afgesonder moet word - soos die Huweliksformulier stel : „... sodat $\mathrm{u} u$ huisgesin met God en met eer kan onderhou en bowendien ook iets kan hê om aan die behoeftiges mee te deel".

Die afleiding mag nou egter glad nie gemaak word dat dit maar 'n onverskillige of minder-belangrike saak is of die 
Christen vir die armes gee of dit nalaat nie. Dit is wel deeglik roeping wat die gelowige moet vervul. God sal daaroor ook rekenskap vra, want die aanwysings van die Woord is daaroor té duidelik dat dit sommer veronagsaam kan word. Oor die vervulling van hierdie taak sal God dus oordeel. Maar, en dis die belangrike in hierdie verband, die kerk het nie die reg om op hierdie terrein bindende verpligtings op te lê soos wat met die kerklike bydraes gebeur nie.

Dit is hoofsaaklik oor hierdie vrywillige offers vir die diens van barmhartigheid wat die apostels in die verskillende tekste wat reeds genoem is, spreek. Lees ons hulle weer na dan sien ons dat daar staan: „vir die armes onder die heiliges in Jerusalem" (Rom. 15: 26); ,tot versorging van die broeders wat in Judea woon" (Hand. $11: 29$ ); „insameling vir die heiliges" (1 Kor. $16: 1$ ); „diensbetoning aan die heiliges" (2 Kor. $8: 4 ; 9: 1)$; „behoeftes van die heiliges" (2 Kor. 9 : 12); ,aan die armes dink" Gal. 2 : 10). Hier word oor armes en oor heiliges gespreek. Die aanduiding heiliges vir die armes in Jerusalem beteken nie dat hulle voortrefliker was as ander gelowiges elders wat nie in Jerusalem gewoon het nie, en dat hulle juis daarom ondersteuning behoort te ontvang nie. Hier is van geen voorkeur sprake nie, want dié betiteling was 'n gewone uanduiding vir gelowiges of Christene (vgl. 1 Kor. 1 : 2; 2 Kor. 1 : 1; Filipp. $1: 1$; Koloss. 1 : 1).

Nou tref dit die aandag dat sprake is van ,armes onder die heiliges" en van ,aan die armes dink". Dit mag voorkom asof hier bloot van armversorging sprake is. Maar ons lees ook van „broeders in Jude?" en van ,diensbetoning of insameling vir die heiliges", asook van ,behoeftes van heiliges". Dan is die armes nie direk ter sprake nie. Dan staan daar in Handel. 24 : 17 ook dit: "... om aan my volk aalmoese te bring en offers", en Paulus wys dan beslis heen n'a die oorbring van die kollekte na Jerusalem. Moontlik mag daarmee meer as persoonlike of gesins-versorging van armes aangedui word, sodat nadere ondersoek nodig is.

In die Almanak (Geref. Kerk) van 1956 word in verband met 2 Kor. 8 en 9 die volgende gesê: „Dit gaan hier wel nie om traktement (bedoel word: kerklike bydraes - D.K.) in eintlike sin nie, m:xar om steun vir die hulpbehoewende gemeente van Jerusalem, dus sustentasie" (in die Art. oor Die Tiendes). Grosheide gaan verder as hy sê dat die kollekte is vir die kerk en armes, of 'n insameling vir die diens van die Here (Bottenburg, 1 Kor. p. 556). Greydanus weer sê dat dié wat gehelp word in die algemeen die gelowige Jode is (Bottenburg, Romeine p. 649). Ook die uitspraak "broeders in Judea" skyn in dieselfde rigting te wys. Moontlik gaan sommige van hierdie stellings té ver. In elk geval staan dit vas dat ons hier met 'n hulpbehoewende kerk te doen het, die kerk in Jerusalem wat arm was. Die kollekte bly dus verband hou met die armes, al geld dit ook 'n arm gemeente. Hiervan sê Ridderbos (Romeine, Kok, p. 336): dis nie ' $n$ bydrae aan die gemeente as sodanig nie, hoewel die armes se getalle só groot was dat die gedagte telkens by Paulus terugkeer dat die Jerusalemse 
gemeente steun nodig gehad het.

Dit moet dus met beslistheid vir ons vasstaan dat 'n gemeente se verpligting teenoor die armes nié ophou by die armes in sy eie kring nie. Die ywer van Paulus, sodat een gemeente bydra vir materiële versorging van armes in 'n ander gemeente, dien hier as aanwysing en uitdaging. In genoemde artikel in die Almanak word hieroor gesê: „....dit toon ... dat in ons kerklike bydraes nie net aan plaaslike behoeftes gedink moet word nie" (1956, p. 131). (Ons moet net daarop let dat in hierdie artikel gevolgtrekkings uit die Skrifgedeelte gemaak word i.v.m. kerklike bydraes, terwyl ons dit doen i.v.m. die kollekte. Dit stry nie met mekaar nie, want die beginsels vir beide word in dié gedeeltes aangedui). Verder moet ons ook raaksien wat die Skrif in Gal. 6 : 10 stel: „Laat ons dan, terwyl ons geleentheid het, aan almal goed doen, maar die meeste aan die huisgenote van die geloof". Die Bevestigingsformulier stel dit ook duidelik t.o.v. die taak van die diakens: „Bewys weldadigheid aan alle mense, maar insonderheid aan die huisgenote van die geloof". Daar mag geen verslapping op hierdie terrein wees nie, en daar mag geensins teen die grense van die eie gemeente, eie lidmate en geloofsgenote vasgekyk word nie. Hiervoor moet steeds gawes afgesonder en ingesamel word. Daar kan natuurlik ook vir afsonderlike dele en besondere terreine van armversorging gekollekteer word, bv. vir wcse, oues van dae, siekes, geloofsgenote wat ander vervolging ly, mits steeds duidelik bekend gestel wond wasrvoor dit bestem is.
Die sedelike plig van die gelowiges om 'n gawe vir die armes af te sonder, het reeds duidelik uit die gegewens van die Skrif geblyk. Ook is duidelik dat dit op die Sondag moet gebeur, en die beste geleentheid daarvoor is by die samekoms van die gemeente in die erediens waar dit goed inpas en tuishoort. Terloops kan hierby gesê word dat dit stellig die suiwerste volgens Christelike beginsels en praktyk is as ons ál ons bydraes vir en gawes in die kerk by die erediens afdra. Daarmee sal die diakens (wat deesdae soms net kollektante is van kerklike bydraes wat ons uit dankbaarheid na die kerk behoort te bring) ook hulle hande en voete vryer hê vir die werklike uitoefening van hulle amp, sonder om genoodsaak tc wees om soveel tyd te verspil aan werk wat nie tot hul amp behoort nie. Daarmee sal die kerk werklik meer kan optree as 'n uitdeler van die barmhartigheid in Christus Jesus.

Die Skrif het aan ons ook geleer dat die kollekte direk in verband met die voorsiening in die behoeftes van die heiliges moet staan. Ons ken die barmhartigheidsdiens vandag inderdaad só dat indiwiduele persone of gesinne hulp ontvang in hulle nood en ellende, mede deur trooswoorde uit die Heilige Skrif vgl. Bevestigingsformulier van diakens). Aan alle vereistes van die Skrif word egter ook voldoen as groepe mense hulp ontvang - bv. wese, oues van dae, vervolgdes. In hierdie verband kan diakonale hulp baie sinvol uitgebrei word na groepe soos siekes, verstandelik-gekrenktes ens. Selfs die oprigting van hospitale om sulke ellendiges te help, 
is heeltemal gewettig en verder ook gewens.

Dit is verder noodsaaklik dat bystand aan hulpbehoewende kerke verleen sal word - soos die heiden-Christene in die eerste eeu dit aan die kerk van Jerusalem geskenk het. Hierdie terrein en taak het stellig nog nie genoeg aandag in ons tyd geniet nie. Die leiding van die Woord, dat kollektes vir behoeftige gemeentes afgesonder word - in ons kerklike taal van vandag: vir sustentasie - moet deur ons gevolg en uitgevoer word. Beide Jansen (Korte Verklaring van die Kerkorde, p. 53) en Bouwman (Gereformeerd Kerkrecht, I. p. 456) verklaar dat klein en swak kerke, wat nie in hulle eie onderhoud kan voorsien nie, uit liefde deur die sterk kerke gesteun moet word. As bewys hiervoor noem hulle die meergenoemde hulp aan die kerk van Jerusalem volgens die bekende tekste. Hierby noem hulle ook Gal. $6: 2$ - „Dra mekaar se laste en vervul so die wet van Christus". Bouwman voeg daarby dat dit geskied uit Christelike liefde en mededeelsaamheid. En dan sê hy veral ook dat hier eintlik geen verpligting aan kerke opgelê kan word nie (soos bv. die raming vir sustentasie wat vandag in ons kerke die praktyk is - D.K.).

Dieselfde beginsel wat ons aangetref het by die verpligtings van die indiwiduele gelowige, vind ons dus hier weer terug - die Christen kan verplig word om sy kerklike bydrae te gee aangesien dit skuld is, maar geen dwang kan toegepas word by die gawe vir die armes nie. So ook is 'n gemeente verplig om sekere sake te steun, bv. opleiding van bedienaars van die Woord, belange van die kerkverband ens., maar dit is wel 'n ope vraag of ramings vir sustentasie in orde is? Die praktyk in die Gereformeerde Kerk moet op hierdie gebied stellig gereformeer of gesuiwer word om te beantwoord aan die beginsels van die Skrif. Daar kan stellig meer gehandel word soos wat Paulus gedoen het, naamlik om te kollekteer vir ' $n$ behoeftige gemeente. Dit kom in die kerklike lewe voor dat een gemeente, met toestemming van 'n meerdere vergadering, by ander gemeentes gaan kollekteer, bv. vir kerkbou. Hierteen is prinsipieel stellig niks op te merk nie, behalwe miskien dat dié gemeente wat in behoefte verkeer feitlik die inisiatief moet neem en dikwels sy predikant of andere vir hierdie saak moet uitstuur. Die eis van Christelike liefde moet eintlik die andere só dring dat hulle, wanneer die toestand van sake en regverdigheid van steun vasgestel is, vanselfsprekend die hulp aanstuur. Ons dink hier aan wat Paulus noem 'n dankoffer ( 2 Kor. $9: 5$ ), 'n bewys van liefde ( 2 Kor. $8: 24$ ), en die bereidwilligheid van die gemeente ( 2 Kor. $9: 2$ ). Die hulp moet gebring, nie gesoek word nie!

Tog het ons hier iets meer algemeen in gedagte. Ook hier kan 'n parallel met indiwiduele hulp getrek word. By die gawe in die kollekte in die kerk gee die gelowige nie sodat juis ' $n$ bepaalde persoon of huisgesin gehelp word nie. Nee, hy skenk uit dankbaarheid aan die Here vir die ryke genade wat ontvang is, en die diensknegte van Christus - in hierdie geval die diakens - deel dit in sy Naam uit. So ook hoef die kollekte vir 
hulpbehoewende kerke nie besonderlik vir een kerk bestem te wees nie. Ook die kerk gee uit dankbaarheid vir voortdurende en nuwe genade wat ontvang word, sodat minder-bevoorregte kerke gehelp kan word. Die kerkverband, samevoeging van die afsonderlike gemeentes van Christus, sorg dat alles ordelik verloop en hulp gebied word waar dit nodig is. Tog kan ook hierby nog direkte hulp deur een kerk aan 'n ander gebied word; dit is nie slegs moontlik nie maar daarby nog hoogs aanbevelingswaardig.

Reformasie is op hierdie gebied dus 'n vereiste. En in die kerklike lewe kan dit ook heeltemal goed werk. In pluas van ' $n$ vaste en verpligte raming word daar kollektes vir sustentasie in die ge-

- meentes gehou. Die aantal kollektes wat hiervoor afgesonder word, sal afhang van die behoeftes wat bestaan. Wanneer hierdie hele saak en die beginsels wat daaraan ten grondslag lê, goed verstaan en in liefde aangepak word deur die lidmate en die kerke, dan sal daar beslis genoeg middele geskenk word, en beskikbaar wees, om te help waar dit nodig is. Die ywer vir hierdie goeie saak mag selfs só oorweldigend wees dat daar steeds genoegsame fondse beskikbaar is om die hulpbehoewende gemeentes beter en ruimer te help. Dit mag vir kleiner plattelandse kerke moontlik word om gouer selfstandig te beroep, en die vestiging van kerke in nuwe stedelike gebiede mag ook vergemaklik word. Die Skrifwoord is duidelik en verrassend: „Dra mekaar se laste en vervul so die wet van Christus".

Nog een sakie moet aandag geniet, al is dit meer vragenderwys. Indien 'n kerk nou hulpbehoewend is, mag daar miskien gekollekteer word vir die instandhouding van die erediens? Of moet alle kollektes alleen vir die behoeftes van die heiliges wees? (Oor die saak van twee kollektes by een diens word later gespreek). En moet alle hulp dan uit die kerkverband kom? Dit sou moontlik wees om baie hieroor uit te wei, maar dit wil voorkom of die gevare in die praktyk ons teen sodanige kollekte vir eie behoeftes wil waarsku. Só iets sou alleen tog geregverdig kan word as al die gemeentelede hulle plig t.o.v. kerklike bydrae ten volle en gereeld nakom en die kerkraad oortuig is dat daar geen laksheid is waardeur ' $n$ 'tekort ontstaan wat deur so 'n kollekte aangevul moet word nie. Die gevare van selfmisleiding, van traagheid in ywer en flouheid van die liefdesvuur is daarby tog nie net denkbeeldig nie? En is dit nie beter dat die kerkverband met sustentasie intree, waarby beter kontrole moontlik is en tog nog genoegsame steun verleen kan word nie? So iets - ruime voorsiening in werklike behoeftes - kan inderdaad voorkom as die kollektes vir sustentasie werklik dankoffers is wat met bereidwilligheid gebring word.

Wat oor die doel van die insameling bevind is, kan só opgesom word:

a. Daar moet onderskei word tussen kerklike bydraes, wat 'n verpligting vir die gelowige is om na te kom en waarvoor die kerkraad voorskrifte kan gee, en die gawe in die kollekte, wat vrywillig gegee moet word hoewel dit met blymoedigheid gegee moet word. Ook oor hierdie sedelike plig van die gelowige vra God egter rekenskap. 
b. Die doel waarvoor die kollekte bestem moet wees, is die voorsiening in die behoeftes van die heiliges, d.i. vir die versorging van hulpbehoewende gelowiges (en andere).

c. Dié wat versorg moet word, is die armes van die eie gemeente, ander geloofsgenote buite die grense van die eie gemeente, en enigeen wat hulp nodig het. Só word die barmhartigheid in Christus ook in die wêreld geopenbaar.

d. Diegene wat gehelp word, kan persone of gesinne of groepe ellendiges wees.

e. Ook hulpbehoewende gemeentes kom in aanmerking vir versorging. Vir die doeleindes van sustentasie kan dus met die erediens gekollekteer word, en verpligte ramings vir hierdie doel moet liewer nagelaat word .

f. Regte begrip en liefde wat in klinkende dade tot uiting kom, sal meebring dat daar steeds genoegsame middele beskikbaar is om hulp te bied waar dit nodig is - aan persone of aan gemeentes.

Die liefde tot Christus moet in hierdie hele saak die besielende faktor wees. Verder moet ons telkens ook ons seëninge tel. Nie alleen maak God ons tot lede van Sy kerk nie, maar ons mag en moet ook die opbou van die kerk en uitbreiding van Sy koninkryk daadwerklik aanpak en bevorder. Daarvoor vra $\mathrm{Hy}$ ook ons offers vir die kerk en gawes vir die armes, maar verder beslis ook ans hele lewe en volle hart, om Hom bo alles lief te hê en te dien. Daarom bely ons saam met Paulus: „En God het mag om alle genade oorvloedig oor julle te laat wees, sodat julle altyd in alle opsig- te volop kan hê en oorvloedig kan wees tot elke goeie werk" ( 2 Kor. $9: 8$ ).

\section{Wanneer moet gekollekteer word?}

Die kollekte is, volgens die voorskrif van God in sy Woord, verbind aan die eerste dag van die week - dus aan die Rusdag of Sondag. Verder is ook vasgestel dat die kollekte die beste en sinvolste tydens die samekoms van die gemeente met die erediens op daardie dag kan opgeneem word. Nou sê ons met die erediens, maar ons moet nog bepaal wanneer, op watter tydstip van die erediens, dit behoort te gebeur.

Uitgangspunt hierby moet dan wees dat God oral en altyd teenwoordig is in Sy skepping. Ons lees in die Nederlandse Geloofsbelydenis (art. 12) immers: „Ons glo dat die Vader deur sy Woord, dit wil sê deur sy Seun, die hemel, die aarde en alle skepsele uit niks geskape het... ; en $\mathrm{Hy}$ het aan elke skepsel sy wese, gestalte en gedaante en verskillende dienste gegee om sy Skepper te dien. Dat $\mathrm{Hy}$ ook nou nog almal onderhou en regeer na sy ewige voorsienigheid en deur sy oneindige krag..." Niks is of kan bestaan sonder dat die krag van God dit laat wees en dra nie.

Anders is egter die teenwoordigheid of inwoning van God in Sy kerk. In die Ou Testament vind ons dit in die inwoning van God in die midde van Sy volk in die tabernakel of tempel, waar $\mathrm{Hy}$ tussen die gerubs op die versoendeksel van die altaar getroon het. Die Skrif sê ook duidelik dat God op Sion woon. En Esegiël beskryf hoe die heerlikheid van die Here Hom onttrek het uit die tempel en vanaf Jerusalem (10: 19; 
$11: 23$ ). Wat egter nog profeties of sinnebeeldig was tydens die Ou Verbond word werklikheid en waarheid in Jesus Christus - „Die Woord het vlees geword en onder ons gewoon (letterlik in die Grieks: getabernakel) en ons het sy heerlikheid aanskou..." (Joh. 1 : 14). Ons weet van die ergernis wat dit verwek het toe Jesus van die afbreek van die tempel gespreek het, waarby $\mathrm{Hy}$ egter van sy liggaam gespreek het. Die Nuwe Testament sê verder dat die kerk van die Here is die liggaam van Christus, en $\mathrm{Hy}$ is die Hoof daarvan. Hierdie inwoning van God is dus iets besonders, omdat dit ook beteken die genadige inwoning van God by almal wat deur Christus verlos is en in Hom glo - by hulle woon die Gees van God in die harte en lewens. Nie net die kerk van Christus is 'n tempel van die Heilige Gees nie maar ook die afsonderlike gelowige (1 Kor. 3 : 17).

Hier moet nou verder goed onderskei word. Christus het gesê dat die ontmoeting van God nie meer beperk is tot 'n bepaalde plek of geleentheid nie (nie Jerusalem, die tempel, of Gerisim nie) maar dat aanbidding in gees en waarheid bepalend is (vgl. Joh. 3 : 21vv.). In die binnekamer kan die Christen dus voor God verskyn en Hom ontmoet. Dit kan tewens op enige plek of tyd gebeur, mits dit in gees en waarheid geskied. Dus ook waar die huisgesin saamkom, kan 'n ontmoeting met God plaasvind en Sy teenwoordigheid ervaar word. Hierdie samekomste is inderdaad nodig vir elke gelowige en huisgesin, want die verborge en stille omgang met God is van gewigtige betekenis vir alle gelo- wiges en mag nooit verwaarloos word nie.

Tog is die samekoms van die gemeente voor die aangesig van God in die erediens nog iets andersoortigs, en dit moet in sy bepaalde karakter ook raakgesien word. Christus self het gespreek van twee of drie wat in sy Naam saamkom, en dan is Hy in hulle midde (Matth. $18: 20$ ). Natuurlik hoef dié teks aie alleen na openbare samekomste van die gemeente te verwys nie. Dog ons iref nog meer gegewens in die Skrif aan. So lees ons bv, in Joh. 20 : 19 dat Jesus na sy dissipels gekom het terwyl hulle agter geslote deure vergader het. Ook weet ons dat die Heilige Gees uitgestort is terwyl ,hulle almal eendragtig bymekaar was" Hand. $2: 1$ ), en verder dat Petrus en Johannes ,saam na die tempel opgegaan het op die uur van gebed..." (Hand. 3 : 1). In Hand. 20 lees ons dat Paulus die dissipels toegespreek het toe hulle op die eerste dag van die week vergader het om brood te breek. Mooi sê Kuyper hiervan: „Overal waar nu de gemeente samenkomt, verschijnt God, blinkende voor het zielsoog, in het midden van zijn Zion" (Onze Eeredienst, p. 181).

In die lig van die bostaande en ander gegewens van die Skrif weet ons dat die kerkgebou nie die tempel of woonplek van God is nie, maar juis die gemeente wat in die kerk (of enige ander plek), in die voorhowe van die Here, saamkom. Maar ons weet verder dat alle samekomste van die gemeente in die kerk nie noodwendig eredienste is nie. Ook spreek dit vanself dat die erediens nie begin wanneer die eerste lidmaat die 
kerk binne kom nie. Wanneer en hoe is of word dit dan 'n erediens of vergadering van die gemeente voor die aangesig van hulle God?

In die eerste plek moet daar 'n gemeente wees wat kragtens hulle eenheid van geloof voor God saamkom. Bepalend is daarby nié die begeerte van die gelowiges om te vergader nie, maar veel eerder dit dat hulle dit doen in gehoorsaamheid aan die roepstem van God en omdat God hulle saambind - lees $H$. Kategismus vr. 54: ,... die Seun van Cod... vir Hom 'n gemeente wat tot die ewige lewe uitverkies is, deur sy Gees en Woord, in die eenheid van die ware geloof... vergader, beskerm en onderhou..." Duidelik toon die Nuwe Testament verder egter aan dat 'n gemeente ampsdraers moet hê - leraar, ouderlinge, diakens. Wesenlik is daar dus eregiens eers wanneer die gemeente voor die aangesig van God vergader onder leiding en toesig van die ampsdraers, want God roep deur middel van die ampte saam. Dan is daar nie sommer net 'n groep mense bymekaar vir een of ander doel nie (soos by 'n vereniging), maar gelowiges wat hulle onder leiding van die kerkraad, kragtens die band van die geloof en in gehoorsaamheid aan God se bevel, saam voor die heilige God stel.

Die Skrif gebied verder dat by hierdie samekoms alles ook welvoeglik en ordelik moet toegaan (1 Kor. $14: 40$ ). Luister ons hierna dan is direk duidelik dat die erediens nie aanvang wanneer die eerste lidmaat gaan sit en selfs ook nie as almal hulle plek ingeneem het nie; ook nie as die kerkraad binnegekom het nie. Enige vergadering moet 'n ordelike begin en einde hê, en des te meer so die samekoms van die gelowiges met hulle God. Die optrede van die kerkraad is dus 'n noodsaaklike voorvereiste, en meer spesifiek die optrede van die voorganger of bedienaar van die Woord. Die wettige opening van ' $n$ vergadering geskied deur die voorsitter, en die kerklike samekoms vorm geen uitsondering op die reël nie.-Nou vind ons in die Skrif geen direkte gegewens of voorskrifte hiervoor nie, maar ons moet in gedagte hou, soos eerder opgemerk dat ons weinig oor die orde van die erediens in die Skrif vind. In die Ou Testament lees ons in Exodus 19 dat Moses die volk uit die laer gelei het om God te ontmoet; Numeri 6 vertel van die priesterlike seën wat tot die volk kom; in Josua 8 word verhaal hoe Josua die wet voorgelees het „terwyl die hele Israel met sy oudstes en die opsigters en sy regters aan weerskante van die ark staan - teenoor die Levitiese priesters" (vs. 33); en in Nehemia 8 word gesê dat die hele volk soos een man bymekaar gekom en geluister het na die voorlesing van die wet deur Esra, skrifgeleerde en priester. Bekend is ook die laaste vers van Ps. 134 - die seën van die Here word uitgespreek oor die volk. Paulus se briewe, aan gemeentes van Christus geskryf, begin formeel en plegtig met ' $n$ aanhef volgens die algemene briefvorm van daardie tye, en sluit ook op ' $n$ bepaalde wyse af met 'n seëngroet aan die kerk. Wanneer Jesus na sy opstanding aan sy dissipels verskyn, begroet $\mathrm{Hy}$ hulle ook met 'n „Vrede vir julle!" (Lukas 24 : 36; Joh. 20 : 19). In hierdie Skrifgegewens lê tog vir ons 
aanduidings, en ons weet ook dat die samekomste in die sinagoges - waar aan Jesus self deel gehad het - ook plegtig geopen en gesluit is.

In die Gereformeerde Kerke vind ons reeds vanaf die dae van die Hervorming dié gebruik dat die plegtige opening van die samekoms van die gemeente in die Naam van die Here gedoen word (vgl. Matth. 18:20), verkieslik met 'n gepaste Skrifwoord. Reeds baie oud is die gebruik van Psalm 124:8 hierby. Hierdie woorde - „Ons hulp is in die Naam van die Here wat hemel en aarde gemaak het" - - is besonder sinvol om hier uitgespreek te word. Duidelik spreek Ps. 124 van al die gevare wat die gelowiges bedreig, maar ook van die hand van die Here wat bewaar en gered het, en met die laaste vers bely die volk van die Here dat húlle by Hom alleen wil skuil. Met hierdie woorde dui die gemeente van Christus dus aan dat hulle hul afsonder van die wêreld met al sy moeite, sorge en besorgdhede, en dat die aangesig en gedagtes op God gerig en gekonsentreer word. Só dus begin die erediens, en wat daaraan voorafgegaan het, soos bv. orrelspel, oefening van Psalms deur die gemeente, afkondigings e.d.m. hoort wesenlik nie tot die erediens nie. $\mathrm{Na}$ die opening of votum volg die seën van God wat op die gemeente gelê word en die verrigtings word voortgesit, steeds onder leiding van die kerkraad, met lofsang, geloofsbelydenis, gebed, Skriflesing, preek, e.d.m.

Die vergadering of samekoms van die gemeente met hulle God moet egter ook 'n sinvolle, tewens ordelike en welvoeglike, einde vind. Hierby moet weereens in gedagte gehou word dat nie die kerkgebou die woonplek van God is nie maar die gemeente van Christus. Die erediens het dan ook sy afsluitingspunt wanneer die gemeente nie meer as gemeente saamvergader is nie. Ook hier sou dit beslis onordelik en onwelvoeglik wees om die grens van die samekoms te soek by dié punt wanneer die laaste lidmaat die kerkgebou verlaat. Daarom spreek dit vanself dat die slotseën, wat deur die voorganger uitgespreek word, die sluitingspunt vorm. Die gemeente gaan daarna weer na hulle huise, keer dus terug na die worstelstryd van die lewe nadat hulle versterk en toegerus is met Woord en Sakramente en deur die innige gemeenskap met God, maar dit gebeur alleen nadat hulle weer toegerus is met die seën van die Here. Só weet hulle dat midde in die wêreld God nog met hulle is en dat $\mathrm{Hy}$ steeds by hulle bly. Soos wat die Here Jesus se werk op aurde afgesluit is toe $\mathrm{Hy}$ in die hemel opgevaar het met Sy hande seënend uitgestrek (Luk. 24:51), weet die gemeente dat $\mathrm{Hy}$ nou nog seën skenk aan Sy kerk vanuit die hemel, en dit word deur Sy dienskneg aan Sy volk meegedeel. Binne hiérdie grense - die votum of belydenis van afsondering aan die begin en die seën van die Here aan die einde - moet dus alle verrigtings van die erediens ploasvind.

Hierdie grense van die erediens is egter meer as net bloot formeel, want dit word juis bepaal deur die inhoud van die hele samekoms. Want dis God wat saamkom met sy volk, en hulle voor Hom. In die diens is daar naamlik handelinge van die kiant van God: die oplegging van seën, afkondiging van die Wet, Skriflesing en prediking, uitdeling van 
Sakramente, e.d.m. En daar is handeling van die kant van die gemeente: die sang, geloofsbelydenis, gebed, gebruik van Sakramente, die kollekte. Oor albei hicrdie handelings spreek die Kategismus in Sondag 38, waar o.a. sprake is van die hoor na die Woord en van die bring van liefdesgawes aan die armes. Die Kategismus se bedoeling is nie om 'n volledige en uitputtende beskrywing van die erediens te gee nie, want dan sou in elke erediens noodwendig bediening van Sakramente moet plaasvind. Nee, hoofsake word deur die Kategis. mus aangestip om te toon wat tot die Sondag en die erediens behoort. Hierby moet ons egter daarop let dat dit wat tot die erediens gereken word, by ons ook binne die grense daarvan plaasvind. Ongetwyfeld sal daar groot ontevredenheid heers as bv. die gebed, of prediking, of sakramentsgebruik of slotsang eers ná die uitspreek van die seën sou volg. Daarom vind ons hier 'n aanduiding dat die kollekte beslis wel binne daardie grense moet plaasvind.

Ons moet ons weer daaroor besin dat by die kollekte die klem nie op die geld val nie, maar op die gawe van dankbaarheid, op die genade van God om te gee en te kan gee - dus hoofsaak is die geestelike karakter van die kollekte. Opmerklik bly die feit dat Paulus in sy spreke oor die kollekte nêrens van 'n geldstuk melding maak nie, maar steeds die aandag vestig op die genade, die dienswerk, die hulp, die beoefening van gemeenskap - dus die dank en liefdebetoon. Tereg het iemand gesê dat daar wesenlik van offerande sprake is. En die verband van die kollekte met die offer van Christus moet steeds voor oë gehou word. In die hele erediens, ook in die kollekte, gaan dit daaroor dat aan God die eer gegee word. Dit gaan om God, om Christus, en oor hulle wat deur God ook aan die kerk geskenk word sodat die geloof en liefde ook prakties tot uitoefening sal kom. Want Christus self het gesê dat ons die armes altyd by ons sal hê (Joh. 12:8).

Nog 'n saak moet hierby in ag geneem word. Die toenadering van God tot sy volk geskied vandag nie meer deur 'n visioen of stem uit die hemel of iets "dergeliks nie, maar deur die verborge inwoning van die Heilige Gees en deur die diens van die ampte. In dic ampte tog word Christus verteenwoordig; in die ampte tree die teenwoordigheid van die Here sigbaar en uitwendig na vore. En die drie ampte van leraar, ouderling en diaken is juis uitdrukking van die drieërlei amp van Christus (vgl. H. Kateg., vr. 31). Die leraar is profeet --hy bring die Woord van God tot die gemeente; die ouderling is koning - hy oefen regeermag in die kerk uit; die diaken is priester - hy neem offerandes op en verrig barmhartigheidsdiens. Natuurlik is die uitoefening van hulle ampte nie net tot die erediens beperk nie, maar dáár moet dit ook 'n plek vind. Wat gebeur nou? Die leraar verkondig die Woord. Die ouderling hou toesig oor die gemeente (om te sien wie daar is en wie ontbreek), hy sien toe dat alleen wettig-geroepenes voorgaan en hy hou ook toesig oor die leer van die bedienaar van die Woord. Bekend is dit bv. dat in die tyd van die Doleansie in Nederland ouderlinge by geleentrede opgestaan het direk na die preek en voor die gemeente 'n verkeerde leer 
veroordeel het, en nou nog is dit so dat as daar geen ouderling is nie die predikant nie 'n erediens mag hou nie. Die toesig oor die bediening van die Sakramente vind in die diens ook plaas.

In hierdie raamwerk moet nou die diakens se optrede gesien word. Indien die opneem van die kollekte verskuif word tot ná die afsluiting van die erediens, by die uitgaan uit die kerk, dan beteken dit dat die taak van insameling deur die diakens in die erediens op nonaktiwiteit gestel word. Dit hou tog 'n mindere waardering van die ampswerk van die diaken in, en dit mag nie waar al die ampte gelykwaardig is nie. $\mathrm{Ja}$, dit is wel nog in die kerkgebou (of by die drumpel) maar die gemeente is die kerk of woonplek van die Here en nie die gebou nie. Wanneer die gemeente dus opgehou het om saamvergaderde volk van God te wees, om in daardie innige gemeenskap ook hulle godsdiens uit te oefen, moet alle verrigtings van die erediens ook reeds voltooi en afgehandel wees. Mens wonder of dit nie miskien een van die oorsake is wat daartoe bydra dat die amp van die diaken soms nie so hoog geag word nie -- 'n rede miskien waarom die diakensamp deur menige lidmat en selfs kerkraadslid beskou word as oefenskool vir die ouderlingsamp? Onbewus mag hierdie toedrag van sake tot hierin 'n rol speel.

Wanneer ons dus let op die hele wese en karakter vian die erediens èn die kollekte, dan is dit duidelik dat die gawe vir die diens van barmhartigheid ongetwyfeld ' $n$ wesenlike deel van die samekoms van die gemeente vorm. Weereens ontvang die gemeente, wanneer dit onmiddellik voor God staan, die rykdom van die genade in Christus. Naas die gebed en sang bied die kollekte 'n geleentheid tot praktiese en konkrete belewing van dankbaarheid. Die kollekte by die deur is misplaas, in tyd en plek, omdat dit buite die grense van die diens val. Iets anders is dit natuurlik om twee insamelings te hou - een tydens en een na die diens. Vir die diens van barmhartigheid moet in die diens gekollekteer word. Insamelings vir besondere doeleindes, bv. vir sending, Bybelverspreiding, e.d.m. pas natuurlik goed aan by die diens en kan sonder beswaar na die diens gehou word - al ons bydraes behoort tog by die kerk afgedra te word. Selfs vir die kerk (of instandhouding van die erediens) kan ingesamel word (na die diens), hoewel dit stellig beter is om die gemeentelede op te voed om só te gee dat 'n kollekte vir hierdie doel nie nodig is nie!

Sommige kerke, wat die kollekte reeds ' $n$ plek in die erediens gee, plaas dit so ongeveer in die "middel" van die diens. Dan staan dit wel in verband met die gebed en dit mag sinryk wees, want waar in die gebed in woorde die dankbaarheid uitgedruk is, word dit by die kollekte in 'n daad uitgedruk. Maar dit is beslis nie die beste en paslikste geleentheid nie. Baie beter is dit na die preek en dankgebed, voor die slotsang. Ons gee uit dankbaarheid vir al die gawes van God se genade, maar in besonder vir dié wat weer in die samekoms ontvang is. Die prediking van die Woord het weer Jesus Christus aan ons voorgehou, ons het weereens besef dat ons as armes ryk gemaak word deur Sy genade, en dan gee ons van die stoflike 
seëninge, wat God aan ons gegee het, sodat in die behoeftes van die heiliges voorsiening gemaak kan word. Ons gee uit dankbaarheid aan God, die diakens samel dit in, en deur die diakens deel $\mathrm{Hy}$ dit uit aan dié wat minder-bevoorreg is, aan hulle wat Hy juis deur middel, en as gevolg van, ons dankbaarheid wil versorg. As gemeente gee ons aan God offers van dankbaarheid, en Christus deel dit deur middel van Sy ampsdraers uit as 'n hernude bewys en teken van Sy genade en sorg vir liggaam en siel. Dan kom die kollekte werklik tot sy reg, omdat dit in direkte en sinvolle verband met die hele diens staan. Die opneem van die kollekte geskied verder alleen na behoorlike afkondiging - en hoe skocn klink die Skrifwoorde: "Vir die behoeftes van die heiliges" of die woorde vin ons Kategismus: "Christelike liefdegawe aan die armes". Daar moet ook vermeld word vir welke besondere deel van die voorsiening ingesamel word. Só gesien, is die kollekte 'n wonderlike geleentheid wat God ons deur sy genade gegee het om ons diepgevoelde dank aan Hom tot uitdrukking te bring en om vir ons medemense tot seën in 'n harde en gevoellose wêreld te wees. Wie hiermee nie saamstem nie, moet homself ondersoek of hy al ooit die ryke en diep-geestelike betekenis van die kollekte versta:in het?

Samevattend kan oor die plek van die kollekte gestel word:

a) Daar moet onderskei word tussen die teenwoordigheid van God in die hele skepping en Sy toenadering tot $\mathrm{Sy}$ volk in die tabernakel, tempel en kerk van Christus.

b) Die kerkgebou is nie die tempel van God nie, want na die koms van Christus is Sy gemeente die woonplek van die Heilige Gees.

c) Die openbare samekoms van die gemeente word saamgestel onder leiding en toesig van die ampte, wat Christus verteenwoordig.

d) By die erediens moet alles ordelik en welvoeglik toegaan, en daarom moet daar 'n spesifieke begin- en eindpunt wees en alle verrigtings moet binne hierdie grense afgehandel word.

e. Die votum is die begin en die uitspreek van die seën die slot van die vergadering van die gelowiges voor die aangesig van hulle God.

f. Die kollekte - as deel van die godsdiensoefening van die gemeente, as 'n daadwerklike offerande van dank moet beslis deel vorm van die erediens en mag dus nie verskuif word tot na die afsluiting van die diens nie.

g) Die diakens mag ook nie op nonaktiwiteit gestel word gedurende die samekoms nie - in Bybelse tyd het hulle ook met die samekomste die tafels bedien.

h) Die beste plek vir die kollekte is ná die preek en dankgebed - as dankbaarheidsbetoon vir die genadegawes wat weer opnuut ontvang is, onder meer in die prediking van die Woord.

i) Alleen wanneer die geestelike aard van die kollekte beter verstaan word, sal dit meer tot sy reg kom, sodat God sy verskuldigde eer ontvang en in die behoeftes van die heiliges deeglik voorsien word.

4. Slot.

Een van die gevare wat die Christen bedreig, is dat hy gewoon raak aan die wondere van God in die lewe en der- 
halwe afstomp om nie meer die diepgeestelike betekenis van sake raak te sien nie. Ook wat die kollekte betref, kan die so lig gebeur dat dit beskou word as 'n lastige en tyd-rowende gebeurtenis was miskien op 'n ander en makliker manier afgehandel kan word - blote vorm dus! Maar hierdie deel van ons godsdiens mag nooit vir ons 'n leë en ydele vorm word nie. In soverre as wat dit wél in die praktyk die geval is, is dit alreeds ' $n$ aanduiding van insinking van die gehalte van ons geestelike lewe. Daarom is hierdie besinning nodig en herwaardering van ons geestelike skatte noodsaaklik. Altyd weer moet ons ter harte neem die waarskuwende woorde van die Skrif:

"Hieraan het ons die liefde leer ken, dat $\mathrm{Hy}$ sy lewe vir ons afgelê het; en ons behoort ons lewe vir die broeders af te lê. Maar wie die goed van die wêreld het en sy broeder sien gebrek ly en sy hart vir hom toesluit, hoe bly die liefde van God in hom?" ( 1 Johannes 3:16, 17).

Viljoenskroon. D. KEMPFF. 